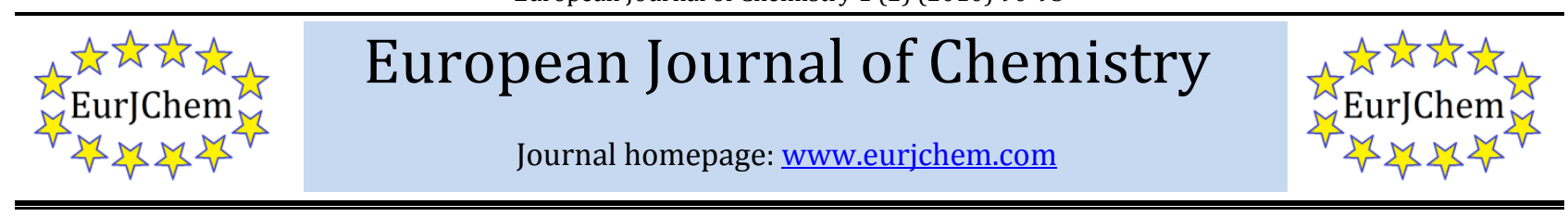

\title{
Synthetic applications of benzothiazole containing cyanoacetyl group
}

\author{
Ahmed Ali Faddaa, Fathy Mohamed Abdelrazekb, ${ }^{\text {, }}$ Khaled Samir Mohameda, \\ Howayda Mohamed Mostafa Ghietha and Hassan Ali Etmana \\ a Chemistry Department, Faculty of Science, Mansoura University, Mansoura, 35516, Egypt \\ b Chemistry Department, Faculty of Science, Cairo University, Giza, 12613, Egypt \\ ${ }^{*}$ Corresponding author at: Chemistry Department, Faculty of Science, Cairo University, Giza, 12613, Egypt. Tel.: +202.35676601; fax: +202.35727556 \\ E-mail address: prof.fmrazek@gmail.com (F.M. Abdelrazek).
}

\section{ARTICLE INFORMATION}

Received: 2 April 2010

Received in revised form: 14 April 2010

Accepted: 14 April 2010

Online: 30 June 2010

\section{KEYWORDS}

\section{Benzothiazole}

Pyridopyrimidine

Thienopyridine

Oxazole

Chromenopyridine

Diazepinone derivatives

\section{Introduction}

Thiazoles and benzothiazole derivatives represent a well known important group of heterocyclic compounds due to their biological and pharmaceutical activities. Thus many diverse biological activities such as bactericidal, pesticidal, fungicidal, insecticidal, anticonvulsant, tuberculostatic, anti-inflammatory, and antithyroidal have been found to be associated with thiazole and benzothiazole derivatives. Benzothiazoles with a cyanomethyl group at position-2 have been the subject of extensive study in the recent past. Numerous reports have appeared in the literature, which highlight their chemistry and uses. However, heterocycles containing cyanoacetyl group are relatively unexplored, probably because their preparation involves displacement of the halide in halo-acetyl substituted heterocycles with e.g. cyanide ion [1], or from an alkyl carboxylate using acetonitrile in the presence of a strong base like sodium amide which usually afforded low yields of impure products [2]. Acetyl chloride itself is not particularly useful in this respect since it undergoes dimerization [3]. Cyanoacetylation of uracils or their derivatives [4-6] and enamines [7] has been reported to be successfully achieved by heating the respective substrate with a mixture of acetic anhydride and cyanoacetic acid as a cyano-acetylating mixture. The structure of the reactive species formed in this case has been assigned as a cyano-ketene. The use of this cyanoacetylating mixture (cyanoacetic acid and acetic anhydride) has somehow been forgotten and instead other less convenient reagents like the pyrrole derivative $\mathbf{1}$ has been used [8] (Scheme 1). The phenolic ester $\mathbf{2}$ of cyanoacetic acid is also suggested for cyano-acetylation since it generates cyano-ketene when heated [9]. In the last two decades, we have been involved in a program aiming to develop new simple procedures or novel precursors for the synthesis of heterocyclic compounds of biological interest to be evaluated as biodegradable agrochemicals [10-14]. In continuation with this program some heterocyclic compounds containing the benzothiazole nucleus were required for biological activity studies. 2-(Benzo $[d]$ thiazol-2-yl)-3-oxopentanedinitrile, 4, (obtained by cyano-acetylation of 3 ) seemed a versatile candidate to fulfill this objective (Scheme 2).<smiles>CCCCCCCCC(=O)n1nc(C)cc1C</smiles><smiles>N#CCC(=O)Oc1ccc([N+](=O)[O-])cc1[N+](=O)[O-]</smiles>

Scheme 1<smiles>CC(C(=O)CC#N)C(N=C1COCC1O)C(=O)O</smiles>

Scheme 2

\section{Experimental}

All melting points are recorded on Gallenkamp electric melting point apparatus. The IR spectra $v\left(\mathrm{~cm}^{-1}\right)(\mathrm{KBr})$ were recorded on a Perkin Elmer Infrared Spectrophotometer Model 157. The ${ }^{1} \mathrm{H}$ NMR spectra were obtained on a Varian Spectrophotometer at $200 \mathrm{MHz}$, using TMS as an internal reference and DMSO- $d_{6}$ as solvent. The ${ }^{13} \mathrm{C}$ NMR spectra were recorded on JEOL-ECA500 (National Research Center, Egypt). 
The mass spectra (EI) were recorded at $70 \mathrm{eV}$ with Kratos MS equipment and/or a Varian MAT 311 A Spectrometer. Elemental analyses (C, $\mathrm{H}$ and $\mathrm{N}$ ) were carried out at the Micro analytical Center of Cairo Univ., Giza, Egypt.

\subsection{2-(Benzo[d]thiazol-2-yl)-3-oxopentanedinitrile, 4}

To a solution of cyanoacetic acid $(0.85 \mathrm{~g}, 0.01 \mathrm{~mol})$ and acetic anhydride $(15 \mathrm{~mL})$ that was heated on water bath for 5 min , 2-(benzo[d]thiazol-2-yl)acetonitrile (3) (1.74 g, $0.01 \mathrm{~mol}$ ) was added and the reaction mixture was refluxed for $20 \mathrm{~min}$ at 85-95 ${ }^{\circ} \mathrm{C}$. Left to cool, and the formed solid was filtered off, dried and recrystallized from ethanol to afford $1.69 \mathrm{~g} \mathrm{(70 \% )} \mathrm{of}$ 4; mp $275{ }^{\circ} \mathrm{C}$; brown crystals; IR (KBr) $\left(v, \mathrm{~cm}^{-1}\right): 2185,2199$ (2CN), 1700 (CO). ${ }^{1} \mathrm{H}$ NMR (DMSO-d $): \delta, 4.52\left(\mathrm{~s}, 2 \mathrm{H}, \mathrm{CH}_{2}\right), 5.10$ (s, 1H, CH), 6.67-7.50 (m, 5H, Ar-H). MS: (m/z, \%): $241\left(\mathrm{M}^{+}\right.$, 36.8), $201\left(\mathrm{M}^{+}-\mathrm{CH}_{2} \mathrm{CN}, 100.0\right), 173\left(\mathrm{M}^{+}-\mathrm{COCH}_{2} \mathrm{CN}, 20.8\right), 146$ (40.3), 108 (21.5), 69 (84.7). Anal. Calcd. for $\mathrm{C}_{12} \mathrm{H}_{7} \mathrm{~N}_{3} \mathrm{OS}$ : C, 59.74; H, 2.92; N, 17.42. Found: C, 59.92; H, 2.97; N, 17.53.

\subsection{2-(Benzo[d]thiazol-2-yl)-3-(4-chlorophenyl)- acrylonitrile, 5}

To a solution of $4 \quad(2.41 \mathrm{~g}, 0.01 \mathrm{~mol})$ and $p$ chlorobenzaldehyde $(1.41 \mathrm{~g}, 0.01 \mathrm{~mol})$ in ethanol $(20 \mathrm{~mL})$, was added a few drops of piperidine and the reaction mixture was refluxed for $4 \mathrm{~h}$, then left to cool (Scheme 3). The precipitate that formed was filtered off, washed with ethanol and purified by recrystallized from ethanol to afford $2.11 \mathrm{~g}(71 \%)$ of $\mathbf{5} ; \mathrm{mp}>$ $300{ }^{\circ} \mathrm{C}$; yellow powder; IR $(\mathrm{KBr})\left(v, \mathrm{~cm}^{-1}\right): 3119(\mathrm{NH}), 2188$ $(\mathrm{CN}) .{ }^{1} \mathrm{H}$ NMR (DMSO- $\left.d_{6}\right): \delta, 7.32-8.12(\mathrm{~m}$, arom. + vinylic $\mathrm{H})$. MS: (m/z, \%): $298\left(\mathrm{M}^{+}+1,3.8\right), 297\left(\mathrm{M}^{+}, 3.8\right), 259$ (4.4), 174 (14.4), 125 (20.0), 84 (100.0). Anal. Calcd. for $\mathrm{C}_{16} \mathrm{H}_{9} \mathrm{ClN}_{2} \mathrm{~S}$ : C, 64.75; H, 3.06; N, 9.44. Found: C, 64.84; H, 3.17; N, 9.51.

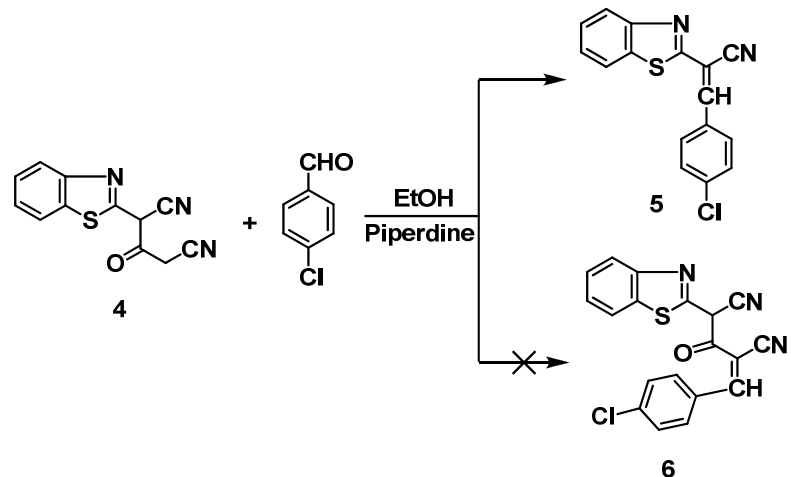

Scheme 3 2.3. 5-Amino-6-(benzo[d]thiazol-2-yl)-7-(4-chlorophenyl)-2-
thioxo-2,3-dihydropyrido[2,3-d]pyrimidin-4(1H)-one, 8

To a mixture of 4 (2.41 g, $0.01 \mathrm{~mol}), p$-chlorobenzaldehyde (1.41 g, $0.01 \mathrm{~mol})$ and 6-aminothiouracil (7) $(1.43 \mathrm{~g}, 0.01 \mathrm{~mol})$ in ethanol $(15 \mathrm{~mL})$, a catalytic amount of piperidine was added (Scheme 4). The reaction mixture was refluxed for $6 \mathrm{~h}$, allowed to cool and poured into ice cold water. The precipitated solid obtained was filtered off, dried and recrystallized from ethanol to furnish $2.72 \mathrm{~g}(62 \%)$ of $8 ; \mathrm{mp} 230^{\circ} \mathrm{C}$; pale yellow powder; IR $(\mathrm{KBr})\left(v, \mathrm{~cm}^{-1}\right): 3402,3389\left(\mathrm{NH}_{2}\right), 3141(\mathrm{NH}), 1698(\mathrm{CO}), 1221$ $(\mathrm{C}=\mathrm{S}) .{ }^{1} \mathrm{H}$ NMR (DMSO- $\left.d_{6}\right): \delta, 6.22\left(\mathrm{~s}, 2 \mathrm{H}, \mathrm{NH}_{2}\right), 7.32-8.49(\mathrm{~m}$, $8 \mathrm{H}, \mathrm{Ar}-\mathrm{H}), 13.51$ (s, 1H, NH), 13.59 (s, 1H, NH). MS: (m/z, \%): $438\left(\mathrm{M}^{+}, 36.4\right), 203$ (18.2), 143 (75.8), 111 (57.6), 63 (100.0). Anal. Calcd. for $\mathrm{C}_{20} \mathrm{H}_{12} \mathrm{ClN}_{5} \mathrm{OS}_{2}$ : C, 54.84; $\mathrm{H}, 2.76 ; \mathrm{N}, 15.99$. Found: C, 54.94; H, 2.82; N, 16.04 .

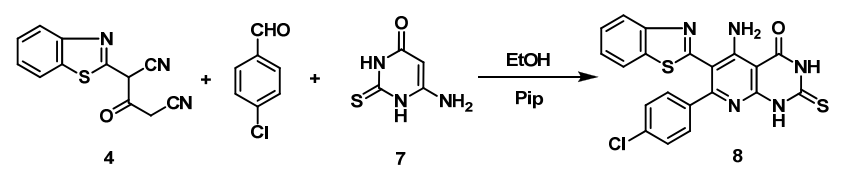

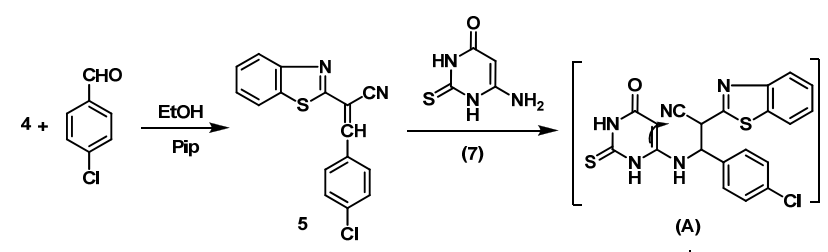

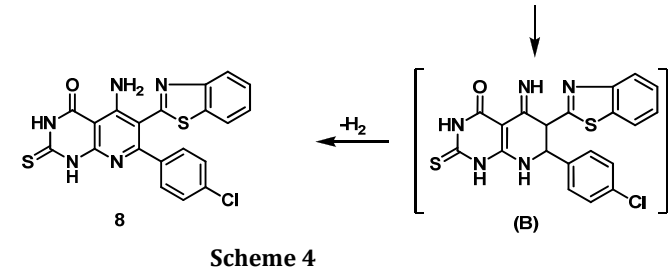

Scheme 4

2.4. 5-Amino-6-(benzo[d]thiazol-2-yl)-7-(1,4-diphenyl-1Hpyrazol-3-yl)-1-methylpyrido[2,3-d]pyrimidine-2,4(1H,3H)dione, 11

To a mixture of 4 (2.41 g, $0.01 \mathrm{~mol})$, 6-amino-1methylpyrimidine-2,4(1H,3H)-dione (9) $(1.41 \mathrm{~g}, 0.01 \mathrm{~mol})$ and 1,4-diphenyl- $1 H$-pyrazole-3-carbaldehyde (10) (2.48 g, 0.01 mol) in DMF $(15 \mathrm{~mL})$, a catalytic amount of TEA was added (Scheme 5). The reaction mixture was refluxed for $6 \mathrm{~h}$, allowed to cool and poured into ice cold water. The precipitated solid obtained was filtered off, dried and recrystallized from ethanol to furnish $2.94 \mathrm{~g} \mathrm{(54 \% )}$ of 11; mp $165^{\circ} \mathrm{C}$; pale brown powder; IR (KBr) $\left(v, \mathrm{~cm}^{-1}\right): 3400,3365\left(\mathrm{NH}_{2}\right), 3220(\mathrm{NH}), 1695$ (amidic CO). ${ }^{1} \mathrm{H}$ NMR (DMSO-d $\left.d_{6}\right): \delta, 3.4\left(\mathrm{~s}, 3 \mathrm{H}, \mathrm{CH}_{3}\right), 6.27\left(\mathrm{~s}, 2 \mathrm{H}, \mathrm{NH}_{2}\right)$, 7.51-8.18 (m, 4H, Ar-H), 9.3 (s, 1H, CH), $10.1(\mathrm{~s}, 1 \mathrm{H}, \mathrm{NH})$. MS: (m/z, \%): $543\left(\mathrm{M}^{+}, 10\right)$. Anal. Calcd. for $\mathrm{C}_{30} \mathrm{H}_{21} \mathrm{~N}_{7} \mathrm{O}_{2} \mathrm{~S}: \mathrm{C}, 66.28 ; \mathrm{H}$, 3.89; N, 18.04. Found: C, 66.26; H, 3.83; N, 18.01 .<smiles>Cn1c(N)cc(=O)[nH]c1=O</smiles>

2.5. 5-Amino-7-(benzo[d][1,3]dioxol-5-yl)-6-(benzo[d] thiazol-2-yl)-1,3-dimethylpyrido[2,3-d]pyrimidine2,4(1H,3H)-dione, 14

To a mixture of 4 (2.41 g, $0.01 \mathrm{~mol})$, benzo[ $d][1,3]$ dioxole5-carbaldehyde (12) $(1.50 \mathrm{~g}, 0.01 \mathrm{~mol})$ and 6-amino-1,3dimethylpyrimidine-2,4(1H,3H)-dione (13) (1.55 g, $0.01 \mathrm{~mol})$ in DMF $(15 \mathrm{~mL})$, a catalytic amount of TEA was added (Scheme 6). The reaction mixture was refluxed for $6 \mathrm{~h}$, allowed to cool and poured into ice cold water. The precipitated solid obtained was filtered off, dried and recrystallized from ethanol to furnish $3.24 \mathrm{~g}(70.5 \%)$ of $14 ; \mathrm{mp} 198-200{ }^{\circ} \mathrm{C}$; pale brown powder; IR (KBr) $\left(v, \mathrm{~cm}^{-1}\right): 3450\left(\mathrm{NH}_{2}\right), 1689(\mathrm{CO}), 1610(\mathrm{C}=\mathrm{N}) .{ }^{1} \mathrm{H}$ NMR (DMSO- $\left.d_{6}\right): \delta, 3.30\left(\mathrm{~s}, 3 \mathrm{H}, \mathrm{CH}_{3}\right), 3.35\left(\mathrm{~s}, 3 \mathrm{H}, \mathrm{CH}_{3}\right), 6.24(\mathrm{~s}, 2 \mathrm{H}$, $\left.\mathrm{NH}_{2}\right), 6.05$ (s, 2H, CH 2$), 6.9$ (d. $\left.1 \mathrm{H}, \mathrm{CH}\right), 7.61(\mathrm{~s}, 1 \mathrm{H}, \mathrm{CH}), 7.7$ (d, 1H, CH), 7.5-8.2 (m, 4H, Ar-H). MS: (m/z, \%): $459\left(\mathrm{M}^{+}, 13\right)$. Anal. Calcd. for $\mathrm{C}_{23} \mathrm{H}_{17} \mathrm{~N}_{5} \mathrm{O}_{4} \mathrm{~S}$ : C, 60.12; $\mathrm{H}, 3.73$; N, 15.24. Found: C, $60.20 ; \mathrm{H}, 3.78 ; \mathrm{N}, 15.31$. 


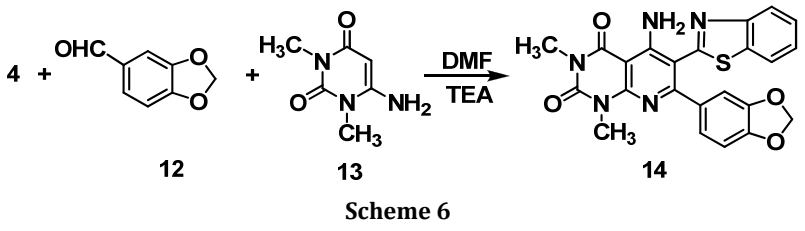

\subsection{2-(Benzo[d]thiazol-2-yl)-4-(4-methylbenzylidene)-3-oxo- pentanedinitrile, 15}

A mixture of 4 (2.41 g, $0.01 \mathrm{~mol}), p$-tolualdehyde $(1.20 \mathrm{~g}$, $0.01 \mathrm{~mol})$ and freshly fused sodium acetate $(1.23 \mathrm{~g}, 0.015 \mathrm{~mol})$ in glacial acetic acid ( $15 \mathrm{~mL})$ was refluxed for $4 \mathrm{~h}$ over a water bath (Scheme 7). The precipitated solid was filtered and recrystallized from ethanol to give $2.37 \mathrm{~g}(69 \%)$ of 15; $\mathrm{mp} 246$ ${ }^{\circ} \mathrm{C}$; IR (KBr) $\left(v, \mathrm{~cm}^{-1}\right): 2220(\mathrm{CN}), 1630(\mathrm{CO}), 1513(\mathrm{C}=\mathrm{N}) .{ }^{1} \mathrm{H}$ NMR (DMSO-d $)_{6}: \delta, 2.49\left(\mathrm{~s}, 3 \mathrm{H}, \mathrm{CH}_{3}\right), 5.70(\mathrm{~s}, 1 \mathrm{H}$, methine proton), 6.30 (s, $1 \mathrm{H}$, vinylic proton), 7.19-8.10 (m, 8H, Ar-H). MS: (m/z, \%): $343\left(\mathrm{M}^{+}, 5\right)$. Anal. Calcd. for $\mathrm{C}_{20} \mathrm{H}_{13} \mathrm{~N}_{3} \mathrm{OS}: \mathrm{C}, 69.95$; H, 3.82; N, 12.24. Found: C, 70.02; H, 3.87; N, 12.31 .<smiles>N#CCC(=O)C(C#N)c1nc2ccccc2s1</smiles>

Scheme 7

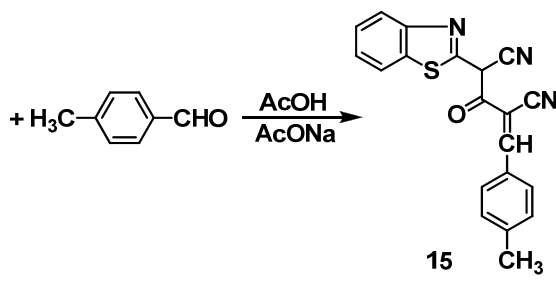

\subsection{2-Amino-3-(benzo[d]thiazol-2-yl)-4H-chromeno[2,3-} b]pyridin-4-one, 16

A mixture of $4(2.41 \mathrm{~g}, 0.01 \mathrm{~mol})$, salicylaldehyde $(1.22 \mathrm{~g}$, $0.01 \mathrm{~mol})$ in ethanol $(15 \mathrm{~mL})$ containing a catalytic amounts of piperidine was refluxed for $4 \mathrm{~h}$. left to cool at room temperature and poured into ice cold water (Scheme 8). The solid product obtained was filtered off, dried and recrystallized from ethanol affording $3.0 \mathrm{~g}(87 \%)$ of $\mathbf{1 6}$; $\mathrm{mp}>300{ }^{\circ} \mathrm{C}$; red crystal; IR (KBr) $\left(v, \mathrm{~cm}^{-1}\right): 3300-3400\left(\mathrm{NH}_{2}\right), 1642(\mathrm{CO}) .{ }^{1} \mathrm{H}$ NMR (DMSO- $\left.d_{6}\right): \delta, 6.93-8.16(\mathrm{~m}, 8 \mathrm{H}, \mathrm{Ar}-\mathrm{H}), 8.60\left(\mathrm{~s}, 2 \mathrm{H}, \mathrm{NH}_{2}\right), 8.77(\mathrm{~s}$, C4-H, pyran). MS: (m/z, \%): $345\left(\mathrm{M}^{+}, 100.0\right), 159$ (39.2), 118 (21.1), 63 (43.5). Anal. Calcd. for $\mathrm{C}_{19} \mathrm{H}_{11} \mathrm{~N}_{3} \mathrm{O}_{2} \mathrm{~S}: \mathrm{C}, 66.07 ; \mathrm{H}, 3.21$; $\mathrm{N}, 12.17$. Found: C, 66.14; $\mathrm{H}, 3.27 ; \mathrm{N}, 12.23$.
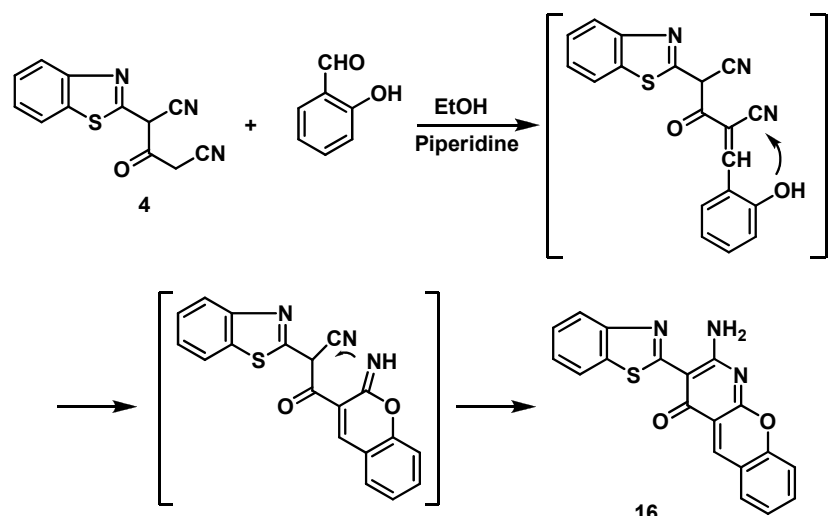

Scheme 8

\subsection{2-Amino-3-(benzo[d]thiazol-2-yl)-benzo[5,6]-4H- chromeno[2,3-b]pyridin-4-one, 17}

A mixture of 4 (2.41 g, $0.01 \mathrm{~mol})$ and 2-hydroxy-1naphthaldehyde $(1.72 \mathrm{~g}, 0.01 \mathrm{~mol})$ in ethanol $(30 \mathrm{~mL})$ was refluxed for $1 \mathrm{~h}$ (Scheme 9). The solid product obtained was filtered off, dried and recrystallized from ethanol to furnish $3.08 \mathrm{~g}(78 \%)$ of $17 ; \mathrm{mp} 260^{\circ} \mathrm{C}$; deep yellow powder; IR (KBr) $\left(v, \mathrm{~cm}^{-1}\right): 3300-3400\left(\mathrm{NH}_{2}\right) .{ }^{1} \mathrm{H}$ NMR (DMSO- $\left.d_{6}\right): \delta, 6.93(\mathrm{~d}, 1 \mathrm{H}$, $\mathrm{CH}), 7.71(\mathrm{~d}, 1 \mathrm{H}, \mathrm{CH}), 7.4-8.19(\mathrm{~m}, 8 \mathrm{H}, \mathrm{Ar}-\mathrm{H}), 8.6\left(\mathrm{~s}, 2 \mathrm{H}, \mathrm{NH}_{2}\right)$, 8.77 (s, 1H, CH). MS: (m/z, \%): $395\left(\mathrm{M}^{+}, 92\right), 311(30.6), 222$ (18.7), 174 (100.0), 69 (69.4). Anal. Calcd. for $\mathrm{C}_{23} \mathrm{H}_{13} \mathrm{~N}_{3} \mathrm{O}_{2} \mathrm{~S}$ : C, 69.86; H, 3.31; N, 10.63. Found: C, 69.94; H, 3.37; N, 10.71.

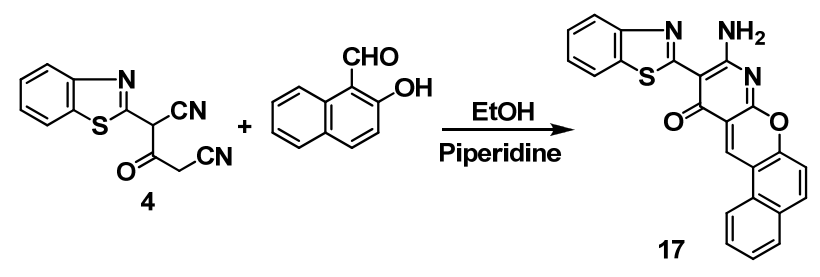

Scheme 9

\subsection{2-(5-Aminoisoxazol-3-yl)-2-(benzo[d]thiazol-2-yl)- acetonitrile, 18}

A mixture of 4 (2.41 g, $0.01 \mathrm{~mol})$ and hydroxylamine hydrochloride $(0.69 \mathrm{~g}, 0.01 \mathrm{~mol})$ in DMF $(15 \mathrm{~mL})$ containing a catalytic amount of TEA was refluxed for $6 \mathrm{~h}$ (Scheme 10). The reaction mixture was left to cool and poured into ice cold water. The precipitated solid was filtered off, dried and recrystallized from ethanol to afford $1.87 \mathrm{~g}(73 \%)$ of 18; $\mathrm{mp}$ $160{ }^{\circ} \mathrm{C}$; brown powder; IR $(\mathrm{KBr})\left(v, \mathrm{~cm}^{-1}\right): 3325,3309\left(\mathrm{NH}_{2}\right)$, 2199 (CN). ${ }^{1} \mathrm{H}$ NMR (DMSO-d6): $\delta, 4.25(\mathrm{~s}, 1 \mathrm{H}, \mathrm{CH}), 7.2(\mathrm{~s}, 1 \mathrm{H}$, $\mathrm{CH}$ ), 7.3-8.1 (m, 4H, Ar-H), 8.19 (s, $2 \mathrm{H}, \mathrm{NH}_{2}$ ). ${ }^{13} \mathrm{C}$ NMR (DMSO$\left.d_{6}\right): \delta, 179.75,166.75,150.04,139.35,127.58,127.19,124.33$, 122.74, 118.08, 115.99, 114.66, 75.52, 40.40, 40.12, 39.84, 39.56, 39.28, 39.01, 38.73. MS: (m/z, \%): $258\left(\mathrm{M}^{+}+2,11.8\right), 201$ (73.7), 174 (100.0), 146 (44.7), 108 (36.8), 69 (89.5). Anal. Calcd. for $\mathrm{C}_{12} \mathrm{H}_{8} \mathrm{~N}_{4} \mathrm{OS}$ : C, 56.24; H, 3.15; N, 21.86. Found: C, 56.19; H, 3.11; N, 21.83.

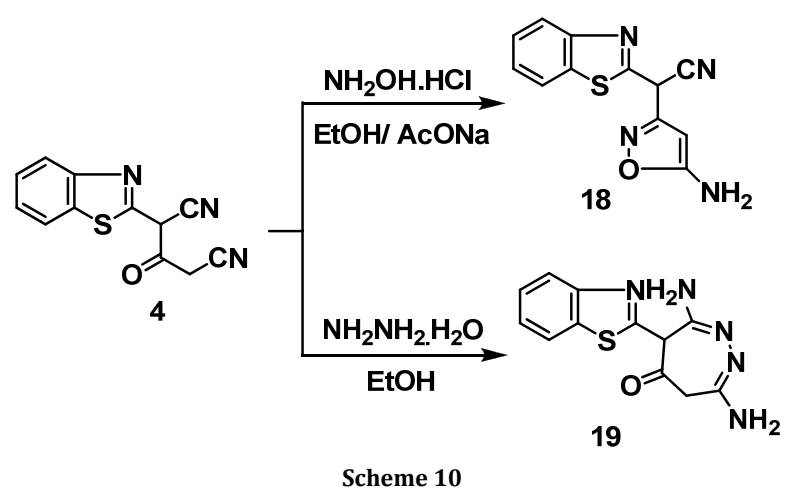

2.10. 3,7-Diamino-4-(benzo[d]thiazol-2-yl)-4H-1,2-diazepin5(6H)-one, 19

To a mixture of 4 ( $2.41 \mathrm{~g}, 0.01 \mathrm{~mol})$ and hydrazine hydrate $(0.75 \mathrm{~g}, 0.015 \mathrm{~mol})$ in ethanol $(15 \mathrm{~mL})$, freshly fused sodium acetate (1.23 g, $0.015 \mathrm{~mol}$ ) was added (Scheme 10). The reaction mixture was refluxed for $4 \mathrm{~h}$, allow to cool at room temperature. The reaction mixture was poured into ice cold water, the solid formed was filtered off, dried and recrystallized from ethanol to afford $2.08 \mathrm{~g}(76 \%)$ of $19 ; \mathrm{mp}>300{ }^{\circ} \mathrm{C}$; off white powder; IR $(\mathrm{KBr})\left(v, \mathrm{~cm}^{-1}\right): 3314,3173 \mathrm{NH}_{2} .{ }^{1} \mathrm{H}$ NMR (DMSO- $d_{6}$ ): $\delta, 2.4: 2.5$ (d.d, $2 \mathrm{H}, \mathrm{CH}_{2}$ ), 3.76 (s, $1 \mathrm{H}, \mathrm{CH}$ ), 7.26-8.12 
(m, 4H, Ar-H, 2NH $), 8.51\left(\mathrm{~s}, 4 \mathrm{H}, 2 \mathrm{NH}_{2}\right)$. MS: (m/z, \%): $275\left(\mathrm{M}^{+}\right.$ +2, 100.0), 273 (M+1 12.8), 176 (23.1), 123 (14.1), 76 (55.1). Anal. Calcd. for $\mathrm{C}_{12} \mathrm{H}_{11} \mathrm{~N}_{5} \mathrm{OS}$ : C, 52.73; H, 4.06; N, 25.62. Found: C, 52.69; H, 4.07; N, 25.65 .

\subsection{2-(Benzo[d]thiazol-2-yl)-3-hydroxy-3-(2-oxo-4-phenyl- 1,2-dihydropyridin-3-yl)- acrylonitrile, 21}

To a mixture of $4 \quad(2.41 \quad \mathrm{~g}, \quad 0.01 \quad \mathrm{~mol})$ and benzalacetophenone $(2.08 \mathrm{~g}, 0.01 \mathrm{~mol})$ in ethanol $(20 \mathrm{~mL})$, a catalytic amount of piperidine was added (Scheme 11). The reaction mixture was refluxed for $12 \mathrm{~h}$, the formed solid was left to cool at room temperature, filtered off, dried and recrystallized from ethanol to afford $2.53 \mathrm{~g}(68 \%)$ of 21 ; $\mathrm{mp}$ $295{ }^{\circ} \mathrm{C}$; yellow powder; IR $(\mathrm{KBr})\left(v, \mathrm{~cm}^{-1}\right): 3441(\mathrm{OH}), 3134$ (NH), $2211(\mathrm{CN}), 1631$ (CO). ${ }^{1} \mathrm{H}$ NMR (DMSO- $d_{6}$ ): $\delta, 7.41-8.09$ (m, 11H, Ar-H), $8.2(\mathrm{~s}, 1 \mathrm{H}, \mathrm{NH}), 9.79$ (s, 1H, OH). Anal. Calcd. for $\mathrm{C}_{21} \mathrm{H}_{13} \mathrm{~N}_{3} \mathrm{O}_{2} \mathrm{~S}$ : C, 67.91; H, 3.53; N, 11.31. Found: $\mathrm{C}, 67.97 ; \mathrm{H}$, $3.56 ; \mathrm{N}, 11.39$.

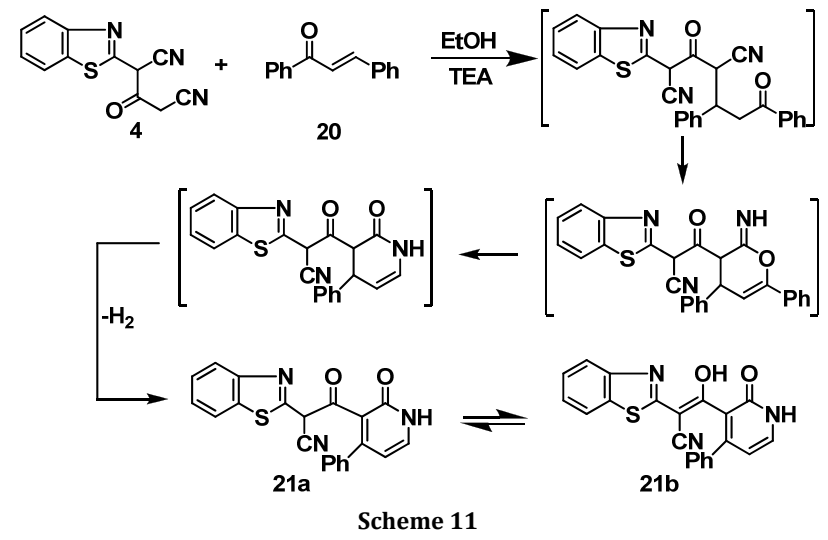

2.12. 2-(5-Amino-1,3-dimethyl-2,4-dioxo-1,2,3,4-tetrahydropyrido[2,3-d]pyrimidin-7-yl)-2-(benzo[d]thiazol-2yl)acetonitrile, 23

To a mixture of $4(2.41 \mathrm{~g}, 0.01 \mathrm{~mol})$ and 6-amino-1,3dimethylpyrimidine-2,4(1H,3H)-dione (13) $(1.55 \mathrm{~g}, 0.01 \mathrm{~mol})$ in glacial acetic acid $(20 \mathrm{~mL})$, freshly fused sodium acetate $(1.23 \mathrm{~g}, 0.015 \mathrm{~mol})$ was added (Scheme 12). The reaction mixture was refluxed for $12 \mathrm{~h}$, left to cool at room temperature, poured into ice cold water. The precipitated solid after neutralization was filtered off, dried and recrystallized from ethanol to afford $3.1 \mathrm{~g} \mathrm{(82 \% )}$ of 23 ; $\mathrm{mp} 260{ }^{\circ} \mathrm{C}$; yellow powder; IR $(\mathrm{KBr})\left(v, \mathrm{~cm}^{-1}\right): 3418,3581\left(\mathrm{NH}_{2}\right), 2216(\mathrm{CN}) .{ }^{1} \mathrm{H}$ NMR (DMSO- $d_{6}$ ): $\delta, 3.25$ (s, 3H, $\left.\mathrm{CH}_{3}\right), 3.37\left(\mathrm{~s}, 3 \mathrm{H}, \mathrm{CH}_{3}\right), 4.89(\mathrm{~s}, 1 \mathrm{H}$, $\mathrm{CH}), 5.9\left(\mathrm{~s}, 1 \mathrm{H}, \mathrm{C}_{3}-\mathrm{H}\right.$, pyridine), $6.22\left(\mathrm{br} ., 2 \mathrm{H}, \mathrm{NH}_{2}\right), 7.30-8.10$ (m, 4H, Ar-H). MS: (m/z, \%): $348\left(\mathrm{M}^{+}-2 \mathrm{CH}_{3}, 15.8\right), 202$ (2.6), 115 (21.1), 97 (47.4), 56 (100.0). Anal. Calcd. for $\mathrm{C}_{18} \mathrm{H}_{14} \mathrm{~N}_{6} \mathrm{O}_{2} \mathrm{~S}$ : C, 57.13; H, 3.73; N, 22.21. Found: C, 57.21; H, 3.81; N, 22.28.
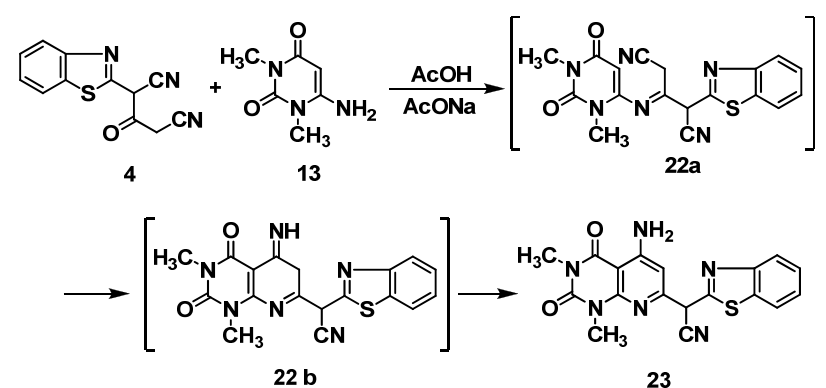

Scheme 12

\subsection{5-Amino-4-(benzo[d]thiazol-2-yl)-3-hydroxythiophene-} 2-carbonitrile, 24

A mixture of 4 ( $2.41 \mathrm{~g}, 0.01 \mathrm{~mol})$, orthorhombic sulfur $(0.32$ g, $0.01 \mathrm{~mol})$, and TEA $(3 \mathrm{~mL})$ were kept on a water bath at 50 $60{ }^{\circ} \mathrm{C}$ for $5 \mathrm{~h}$, left to cool then poured into ice cold water and acidified by conc. $\mathrm{HCl}$ (Scheme 13). The formed solid was filtered off, dried and recrystallized from ethanol to afford 2.19 g $(80 \%)$ of $24 ; \mathrm{mp} 208{ }^{\circ} \mathrm{C}$; orange powder; IR $(\mathrm{KBr})\left(v, \mathrm{~cm}^{-1}\right)$ : $3454(\mathrm{OH}), 3396,3345\left(\mathrm{NH}_{2}\right) .{ }^{1} \mathrm{H}$ NMR (DMSO- $\left.d_{6}\right): \delta, 6.12(\mathrm{~s}$, br., $1 \mathrm{H}, \mathrm{OH}$ ), 6.67 (s, br., $2 \mathrm{H}, \mathrm{NH}_{2}$ ), 7.21-8.32 (m, 4H, Ar-H). ${ }^{13} \mathrm{C}$ NMR (DMSO- $d_{6}$ ): $\delta, 180.14,179.62,166.77,159.64,139.49$, $139.00,134.16,130.25,128.97,127.54,125.60,124.44,123.65$ $122.83,117.90,115.93,112.40,84.65,75.48,45.75,39.84$ 30.73, 29.4. MS: (m/z, \%): $274\left(\mathrm{M}^{+}-1,26.1\right), 258$ (30.4), 201 (100.0), 173 (56.5), 146 (47.8), 122 (30.4), 93 (95.7), 69 (87.0). Anal. Calcd. for $\mathrm{C}_{12} \mathrm{H}_{7} \mathrm{~N}_{3} \mathrm{OS}_{2}$ : C, 52.73; H, 2.58; N, 15.37. Found: C, 52.76; H, 2.61; N, 15.45 .

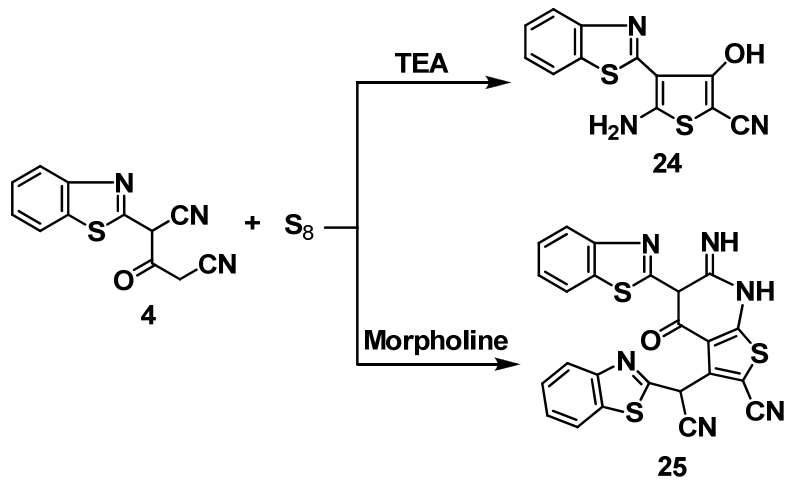

Scheme 13

\subsection{5-(Benzo[d]thiazol-2-yl)-3-(benzo[d]thiazol-2-yl- (cyanomethyl)-6-imino-4-oxo-4,5,6,7-tetrahydrothieno[2,3 b]pyridine-2-carbonitrile, 25}

A mixture of 4 ( $2.41 \mathrm{~g}, 0.01 \mathrm{~mol})$, orthorhombic sulfur $(0.32$ g, $0.01 \mathrm{~mol}$ ), morpholine (few drops) and DMF (3 mL) were kept on a water bath at $50-60{ }^{\circ} \mathrm{C}$ for $5 \mathrm{~h}$, left to cool, poured into ice cold water and acidified by conc. HCl (Scheme 13). The formed solid was filtered off, dried and recrystallized from ethanol to afford $3.58 \mathrm{~g}(72 \%)$ of 25 ; $\mathrm{mp} 183{ }^{\circ} \mathrm{C}$; brown powder; IR $(\mathrm{KBr})\left(v, \mathrm{~cm}^{-1}\right): 3220(\mathrm{NH}), 2195,2220(2 \mathrm{CN}) .{ }^{1} \mathrm{H}$ NMR (DMSO- $\left.d_{6}\right): \delta, 3.6(\mathrm{~s}, 1 \mathrm{H}, \mathrm{CH}), 4.4(\mathrm{~s}, 1 \mathrm{H}, \mathrm{CH}), 7.2-8.1(\mathrm{~m}$, $8 \mathrm{H}, \mathrm{Ar}-\mathrm{H}), 9.8$ (s, 1H, NH, cyclic), 13.7 (bs, $1 \mathrm{H}, \mathrm{NH}) . \mathrm{MS}:(\mathrm{m} / \mathrm{z}$, \%): $470\left(\mathrm{M}^{+} \mathrm{CN}\right), 273$ (13.6), 241 (31.3), 201 (100.0), 146 (30.2), 108 (22.3), 69 (38.9). Anal. Calcd. for $\mathrm{C}_{24} \mathrm{H}_{12} \mathrm{~N}_{6} \mathrm{OS}_{3}$ : C, 58.05; H, 2.44; N, 16.92. Found: C, 58.14; H, 2.49; N, 16.97.

\section{Results and Discussion}

In continuation of our program and following our previous interest [15-20] in the synthesis of new heterocyclic compounds of anticipated biological activity, it has been found that cyanoacetylation of 2-(benzo[d] thiazol-2-yl)acetonitrile, 3, will lead to an excellent building block for the synthesis of target compounds. Thus, when $\mathbf{3}$ was treated with cyanoacetic acid in the presence of acetic anhydride, it afforded the corresponding 2-(benzo[ $d$ ] thiazol-2-yl)-3-oxopentanedinitrile, 4, as tested by thin-layer chromatography (TLC) (Scheme 2).

Reactions of this type have not been previously reported, however they were found to give products in excellent yields under very mild conditions. Moreover, the resulting benzothiazole derivative $\mathbf{4}$ has latent functional substituents, which render it to be a versatile starting substrate for further chemical transformations that open new routes for the 
preparation of substituted benzothiazole derivatives with possible biological activity.

Its structural assignment was proved by spectroscopic analyses. The IR spectrum of the latter product revealed absorption bands at $2185,2199 \mathrm{~cm}^{-1}$ due to two CN groups, a very weak band near $1700 \mathrm{~cm}^{-1}$ that was attributed to the carbonyl group. Its ${ }^{1} \mathrm{H}$ NMR spectrum revealed singlet signals at $\delta 4.52$ and $5.10 \mathrm{ppm}$ due to $\mathrm{CH}_{2}$ and $\mathrm{CH}$ proton, respectively, beside an aromatic multiplet in the region of $\delta 6.67-7.5 \mathrm{ppm}$. Moreover, the mass spectrum showed $\mathrm{m} / \mathrm{z}$ at $241\left(\mathrm{M}^{+}\right), 201\left[\mathrm{M}^{+-}\right.$ $\left.\mathrm{CH}_{2} \mathrm{CN}\right]$ (100\%), 173 [M+- $\left.\mathrm{COCH}_{2} \mathrm{CN}\right](20.8 \%)$.

Now, we have extended our synthetic program to the synthesis of otherwise inaccessible heterocyclic ring system utilizing compound $\mathbf{4}$ as the key starting material. A mixture of 4 and $p$-chlorobenzaldehyde reacted in refluxing ethanol in the presence of catalytic amounts of piperidine to yield a product which may be formulated as $\mathbf{5}$ or $\mathbf{6}$ (Scheme 3). Structure $\mathbf{6}$ was ruled out on the basis of ${ }^{1} \mathrm{H}$ NMR spectrum of the reaction product, which revealed a multiplet at $\delta 7.32-8.12 \mathrm{ppm}$ due to the aromatic and the vinylic proton being embedded in. In addition, the IR spectrum showed absorption bands at 2188 $\mathrm{cm}^{-1}$ due to the CN group, indicating the presence of one cyano group and the absence of any bands in the region of $\mathrm{CO}$ group absorption. The mass spectroscopic measurements showed $\mathrm{m} / \mathrm{z} 297\left(\mathrm{M}^{+}\right)$which indicates structure $\mathbf{5}$.

The structure of $\mathbf{5}$ was further confirmed by an alternative synthesis. The treatment of $\mathbf{3}$ with $p$-chlorobenzaldehyde in refluxing ethanol in the presence of piperidine (catalytic amounts) yielded a product completely identical in all respects (m.p., mixed m.p., IR and ${ }^{1} \mathrm{H}$ NMR) with 5.

Pyrimidine is the parent hetero ring of a very important group of compounds that are extensively studied due to their occurrence in living systems. Compounds containing a pyrimidine ring has been reported to exhibit antibacterial and antifungal as well as anti-HIV activity [21,22]. On the other hand, substitution of a pyridine ring to benzene ring often is compatible with retention of biological activity and occasionally the moiety is an essential part of the pharmacophore. Such substitution of $=\mathrm{N}$ for $\mathrm{CH}=$ is an example of the common medicinal strategy known as bioisosterism. Therefore, 5-amino-6-(benzo[d] thiazol-2-yl)-7-(4-chlorophen yl)-2-thioxo-2,3-dihydropyrido[2,3-d]pyrimidin-4(1H)-one 8 was synthesized by refluxing equimolar amounts of compound 4, 6-aminothiouracil 7 and $p$-chlorobenzaldehyde in ethanol in presence of a catalytic amount of piperidine. The reaction proceeded according to Scheme 4.

The formation of $\mathbf{8}$ can be attributed to the first formation of compound $\mathbf{5}$ as intermediate which undergo Michael reaction with 6-aminothiouracil 7 to yield the nonionisable intermediate A which undergo intra-molecular nucleophilic addition to the $\mathrm{CN}$ group to give the intermediate $\mathbf{B}$ which is aromatized under the reaction condition to afford the final isolable product $\mathbf{8}$ (Scheme 4). The structure of compound $\mathbf{8}$ was proved by its analytical and spectral analyses. The mass spectrum showed a molecular ion peak at $\mathrm{m} / \mathrm{z} 438\left(\mathrm{M}^{+}\right)$. The IR spectrum showed absorption bands at $3402,3389 \mathrm{~cm}^{-1}\left(\mathrm{NH}_{2}\right)$, $3141 \mathrm{~cm}^{-1}(\mathrm{NH}), 1698 \mathrm{~cm}^{-1}(\mathrm{C}=0)$ and $1221 \mathrm{~cm}^{-1} \quad(\mathrm{C}=\mathrm{S}) ;{ }^{1} \mathrm{H}$ NMR (DMSO- $d_{6}$ ) showed three $\mathrm{D}_{2} \mathrm{O}$ exchangeable protons at $\delta 13.51$, 13. $59 \mathrm{ppm}$ due to $\mathrm{NH}$ protons and at $\delta 6.22 \mathrm{ppm}$ due to $\mathrm{NH}_{2}$ beside the aromatic protons. An alternative method for the synthesis of compound $\mathbf{8}$ was achieved by heating benzothiazole derivative 5 with 6-aminouracil (7) in DMF and in the presence of piperidine (catalytic amount) to give a product identical in all respects (m.p., mixed m.p., IR, and ${ }^{1} \mathrm{H}$ NMR) with 8.

Similarly, it was found that refluxing a mixture of compound 4, 1-methyl-6-aminouracil 9 and 3-formylpyrazole 10 in DMF in the presence of TEA afforded the corresponding pyridopyrimidine derivative $\mathbf{1 1}$ (Scheme 5).
The formation of $\mathbf{1 1}$ apparently proceeded according to the previously proposed mechanism and its structure was proved by analytical and spectral analyses. The IR spectrum of $\mathbf{1 1}$ revealed absorption bands at $3400,3365 \mathrm{~cm}^{-1}\left(\mathrm{NH}_{2}\right), 3220$ and $1695 \mathrm{~cm}^{-1}$ (NH and amidic CO group, respectively). The mass spectrum showed the molecular ion peak at $\mathrm{m} / \mathrm{z} 543\left(\mathrm{M}^{+}\right.$, $10 \%)$.

In a similar way, heating $\mathbf{4}$ with an equimolar amounts of pipronal 12 and 1,3-dimethyl-6-aminouracil 13 in DMF in the presence of a catalytic amount of TEA gave the corresponding pyridopyrimidine derivative $\mathbf{1 4}$ (Scheme 6).

On the other hand, it was found that refluxing 2(benzo[d]thiazol-2-yl)-3-oxopentanedinitrile with $p$-tolualde hyde in glacial acetic acid in the presence of freshly fused sodium acetate afforded 2-(benzo[d]thiazol-2-yl)-4-(4methylbenzylidene)-3-oxopentanedinitrile 15 (Scheme 7).

The ${ }^{1} \mathrm{H}$ NMR spectrum of $\mathbf{1 5}$ showed singlet signals at $\delta$ $2.49, \delta 5.70, \delta 6.30 \mathrm{ppm}$ and multiplet signal at $\delta 7.19-8.10 \mathrm{ppm}$ due to $\mathrm{CH}_{3}$, methine proton, vinylic proton and eight aromatic protons, respectively. Also mass spectrum showed molecular ion peak at m/z $343\left(\mathrm{M}^{+}\right)$. Unexpectedly, salicyaldehyde and 2hydroxy-1-naphthaldehyde reacted with $\mathbf{4}$ in refluxing ethanol containing catalytic amounts of piperidine in a different way to that with $p$-chlorobenzaldehyde. Therefore, it was found that refluxing of $\mathbf{4}$ with salicyaldehyde and/or 2-hydroxy-1naphthaldehyde in ethanol in the presence of piperidine afforded the corresponding chromenopyridine and benzochromenopyridine derivatives 16 and 17, respectively (Scheme 8 and 9).

The structures of 2-amino-3-(benzo[d]thiazol-2-yl)-4Hchromeno[2,3-b]pyridin-4-one, 16, and 2-amino-3-(benzo[ $[d]$ thiazol-2-yl)-benzo[5,6]-4H-chromeno[2,3-b]pyridin-4-one 17 were established from their IR, ${ }^{1} \mathrm{H}$ NMR and mass spectra. The mass spectrum of $\mathbf{1 6}$ showed molecular ion peak at m/z 345 $\left(\mathrm{M}^{+}\right)(100 \%)$, while 17 showed the molecular ion peak at 395 $\mathrm{m} / \mathrm{z}\left(\mathrm{M}^{+}, 92 \%\right)$. The IR spectra of both 16 and 17 showed the absence of any peak in the region of $2180-2250 \mathrm{~cm}^{-1}$ and this confirms that both two $\mathrm{CN}$ groups were involved in the reaction, also the presence of two peaks in the region of 3300 $3400 \mathrm{~cm}^{-1}$ due to the $\mathrm{NH}_{2}$ group. ${ }^{1} \mathrm{H}$ NMR spectrum of 16 showed a multiplet signal in the region of $\delta 6.93-8.16 \mathrm{ppm}$ due to eight aromatic protons, in addition to two singlet signals at $\delta$ 8.60 and 8.77 ppm due to $\mathrm{NH}_{2}$ protons and $\mathrm{C}_{4}-\mathrm{H}$ in the pyran ring, respectively. On the other hand, ${ }^{1} \mathrm{H}$ NMR of compound 17 could not be evaluated due to its insolubility in all possible solvents. These above results were found in complete agreement with a previously reported work [22,23]. Moreover, treatment of $\mathbf{4}$ with hydroxylamine hydrochloride afforded 2(5-aminoisoxazol-3-yl)-2-(benzo[d]thiazol-2-yl)-acetonitrile 18 in high yield (Scheme 10).

Structure 18 was suggested for this product based on analytical and spectral data. Thus the mass spectrum of this product showed the molecular ion peak at m/z $256\left(\mathrm{M}^{+}\right), 201$, 174 (100\%). The IR spectrum revealed absorption bands at $3325,3309 \mathrm{~cm}^{-1}\left(\mathrm{NH}_{2}\right), 2199 \mathrm{~cm}^{-1}(\mathrm{CN})$. The ${ }^{1} \mathrm{H}$ NMR (DMSO) spectrum revealed signals at $\delta 7.2,7.3-8.1$ and 8.19 ppm due to $\mathrm{NH}_{2}$, the aromatic and the cyclic methine protons, respectively, and at $\delta 4.25 \mathrm{ppm}$ due to the $\mathrm{CH}$ proton. Treatment of 4 with hydrazine hydrate in refluxing ethanol afforded 3,7-diamino-4(benzo[d]thiazol-2-yl)-4H-1,2-diazepin-5(6H)-one, 19 (Scheme 10).

The IR spectrum of $\mathbf{1 9}$ showed the absence of peaks in the region of $2180-2250 \mathrm{~cm}^{-1}$ due to the $\mathrm{CN}$ group, which indicates that both the $\mathrm{CN}$ groups were involved in this reaction. The mass spectrum of $\mathbf{1 9}$ gave the molecular ion peak at m/z 273 $\left(\mathrm{M}^{+}\right)$. Several isomeric structures of $\mathbf{1 9}$ were possible but the actual isomeric form was confirmed from its ${ }^{1} \mathrm{H}$ NMR which showed doublet of doublet signal at $\delta$ 2.4:2.5 ppm due to $\mathrm{CH}_{2}$ protons, at $\delta 3.76 \mathrm{ppm}$ due to the $\mathrm{CH}$ proton beside the 
multiplet signals at $\delta 7.26-8.12 \mathrm{ppm}$ due to four aromatic protons and at $\delta 8.51 \mathrm{ppm}\left(\mathrm{s}, 4 \mathrm{H}, 2 \mathrm{NH}_{2}\right)$.

Compound $\mathbf{4}$ was also used as a precursor for the synthesis of the pyridine ring. Thus, treatment of $\mathbf{4}$ with benzal acetophenone $\mathbf{2 0}$ in refluxing ethanol containing catalytic amounts of TEA afforded compound 21a or its tautomer 21b (Scheme 11).

The structure of the obtained product was confirmed by its IR, ${ }^{1} \mathrm{H}$ NMR and mass spectrum. The mass spectrum showed the molecular ion peak at $\mathrm{m} / \mathrm{z} 371\left(\mathrm{M}^{+}\right)$. The ${ }^{1} \mathrm{H}$ NMR spectrum of this product did not show any signals around $\delta$ 5-6 ppm due to a $\mathrm{CH}$ proton and instead reveals a singlet $(1 \mathrm{H})$ at $\delta 9.79 \mathrm{ppm}$ attributable to the $\mathrm{OH}$ proton and this confirms that the most stable tautomeric form is the enolic form $\mathbf{2 1 b}$, as reported for $\beta$-diketone. This stability of the enol form is attributed to the intramolecular hydrogen bond and also due to the conjugation which is absent in case of the keto form. This conjugation is also reflected on the color of the product (yellow). The ${ }^{1} \mathrm{H}$ NMR spectrum showed also the presence of multiplet signals at $\delta$ 7.41-8.09 ppm due to eleven aromatic protons and one singlet signal at $\delta 8.20 \mathrm{ppm}$ for the $\mathrm{NH}$ proton. The IR spectrum of this product also confirmed the enol form since it showed absorption bands at $v 341(\mathrm{OH}), 3134(\mathrm{NH}), 2211(\mathrm{CN})$, and only one amide $(\mathrm{C}=0)$ peak at $1631 \mathrm{~cm}^{-1}$.

The fused pyridine ring 2-(5-amino-1,3-dimethyl-2,4dioxo-1,2,3,4-tetrahydropyrido[2,3-d]pyrimidin-7-yl)-2-(benzo [d] thiazol-2-yl)acetonitrile $\mathbf{2 3}$ was synthesized from $\mathbf{4}$ by reaction with 6-amino-1,3-dimethylpyrimidine-2,4(1H,3H)dione 13 in refluxing glacial acetic acid containing catalytic amounts of freshly fused sodium acetate presumably via the intermediates 22a and 22b (Scheme 12).

Structure $\mathbf{2 3}$ was proved by its IR spectrum which revealed stretching frequencies of $\mathrm{CN}$ at $2216 \mathrm{~cm}^{-1}, \mathrm{NH}_{2}$ at 3418, 3581 $\mathrm{cm}^{-1}$. The ${ }^{1} \mathrm{H}$ NMR (DMSO- $\mathrm{d}_{6}$ ) for compound 23 showed multiplet bands at $\delta 7.30-8.10 \mathrm{ppm}$ due to four aromatic protons, and broad band at $\delta 6.22 \mathrm{ppm}$ due to $\mathrm{NH}_{2}$, singlet at $\delta$ $5.9 \mathrm{ppm}$ due to $\mathrm{C}_{3}-\mathrm{H}$ in pyridine ring, singlet signal at $\delta 4.89$ ppm due to $\mathrm{CH}$ proton and two singlet signal at $\delta 3.25,3.37$ ppm due to two $\mathrm{CH}_{3}$ groups. The mass spectrum of 23 showed the molecular ion peak at $\mathrm{m} / \mathrm{z} 348\left(\mathrm{M}^{+}-30\right)$ which represents $\left(\mathrm{M}^{+}-2 \mathrm{CH}_{3}\right)$. The thiophene heterocyclic ring incorporating a benzothiazole moiety was prepared directly from compound 4 . Thus treatment of $\mathbf{4}$ with sulfur element in the presence of TEA (slightly excess) afforded the corresponding thiophene 24, while when the reaction was carried out in the presence of morpholine, it afforded the tetrahydrothienopyridine $\mathbf{2 5}$ (Scheme 13,14).

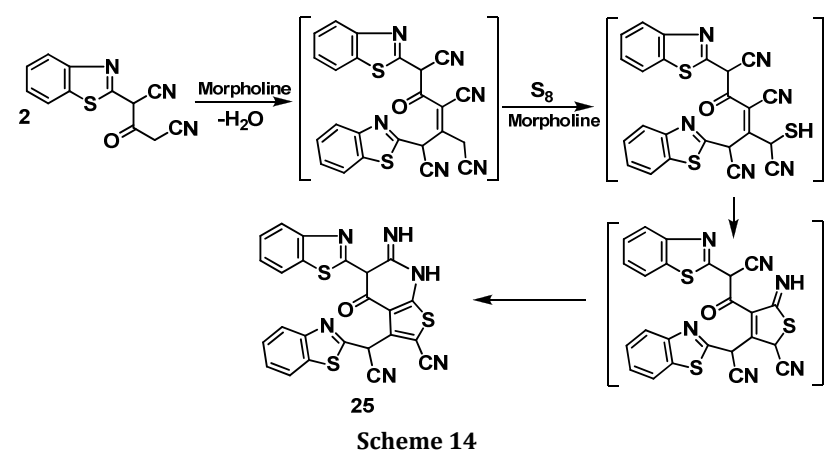

The formation of 5-amino-4-(benzo[d]thiazol-2-yl)-3hydroxy-thiophene-2-carbonitrile $\mathbf{2 4}$ was established by its IR, mass spectrum and ${ }^{1} \mathrm{H}$ NMR. The IR spectrum of $\mathbf{2 4}$ showed broad band at $3454 \mathrm{~cm}^{-1}$ due to $\mathrm{OH}, 3396,3345 \mathrm{~cm}^{-1}\left(\mathrm{NH}_{2}\right)$. The ${ }^{1} \mathrm{H}$ NMR spectrum showed two broad singlet signals at $\delta 6.12$ and $6.67 \mathrm{ppm}$ due to $\mathrm{OH}$ and $\mathrm{NH}_{2}$ protons respectively, in addition to multiplet signal at $\delta 7.21-8.32 \mathrm{ppm}$ due to four aromatic protons. The mass spectrum showed the molecular ion peak at $\mathrm{m} / \mathrm{z} 271\left(\mathrm{M}^{+}-2\right)$.

The IR spectrum of $\mathbf{2 5}$ showed stretching frequencies at $3220 \mathrm{~cm}^{-1}$ due to $\mathrm{NH}$ group and at 2195, $2220 \mathrm{~cm}^{-1}$ for two cyano functions. The mass spectrum showed the molecular ion peak at $\mathrm{m} / \mathrm{z} 470\left(\mathrm{M}^{+}-1\right)$. Structure of $\mathbf{2 5}$ was also established by its ${ }^{1} \mathrm{H}$ NMR (c.f. experimental).

\section{Acknowledgement}

We thank the Alexander von Humboldt Foundation (Germany) for the continual support to F. M. Abdelrazek by granting him repeated research fellowships. This work was supported in part by the Research fund of the Faculty of Science, Cairo University.

\section{References}

[1]. Hayashi, H.; Ohmoto, S.; Somei, M. Heterocycles 1997, 45, 1647-1650.

[2]. Eby, C. J.; Hauser, C. R. J. Am. Chem. Soc. 1957, 79, 723-725.

[3]. Schroeter, G.; Sildler, C.; Sulzbacher, M.; Kanitz, R. Chem. Ber. 1932, 65 432-445.

[4]. Papesch, V.; Schroeder, E. J. Org. Chem. 1951, 16, 1879-1890.

[5]. Muller, T.; Augustin, M.; Werchan, H. G. Z. Chem. 1989, 29, 281-283.

[6]. Isobe, Y.; Tobe, M.; Inoue, Y.; Hayashi, H. Bioorg. \& Med. Chem. 2003, 11,4933-4940.

[7]. Kappe, T.; Stelzel, H. P.; Ziegler, E. Monatsch. Fur Chem. 1983, 114, 953-963.

[8]. Stetinova, J.; Kada, R.; Lesko, J.; Zalibera, L.; Ilavsky, D. Collect. Czech. Chem. C 1995, 60, 999-1008.

[9]. Al-Lohedan, H.; Bunton, C. A. J. Org. Chem. 1981, 46, 3929-3930.

[10]. Fadda, A. A.; Abdelrazek, F. M.; El-Habbal, M. M. Indian J. Chem. 1986, 25B, 194-196

[11]. Abdelrazek, F. M.; Fadda, A. A. Z. Naturforsch., 1986, 41B, 499-501.

[12]. Metwally, N. H.; Abdelrazek, F. M. J. Prakt. Chem. Chem. Zeitung; 1998, 340, 676-678.

[13]. Fadda, A. A.; Amer, F. A.; Zaki, M. E. A.; Samir, K. Phosphorus, Sulfur Silicon \& Relat. Elements 1999, 155, 59-66.

[14]. Abdelrazek, F. M.; Metwally, N. H. Syn. Commun. 2009, 39, 4088-4099.

[15]. Zaki, M. E. A.; Fadda, A. A.; Samir, K.; Amer, F. A. Phosphorus, Sulfur Silicon \& Relat. Elements 2006, 181, 1815-1823.

[16]. Fadda, A. A.; Zaki, M. E. A.; Samir, K.; Amer, F. A. Phosphorus, Sulfur Silicon \& Relat. Elements 2007, 182, 1845-1856.

[17]. Abdelrazek, F. M.; Metwally, N. H.; Sobhy, N. A. Afinidad 2008 65(538), 482-487.

[18]. Abdelrazek, F. M.; Metwally, N. H.; Kassab, N. A.; Sobhy, N. A. J Heterocyclic Chem. 2009, 46, 1380-1385.

[19]. Abdelrazek, F. M.; Elsayed, A. N. J. Heterocyclic Chem. 2009, 46, 949 953.

[20]. Abdelrazek, F. M.; Fadda, A. A.; Elsayed, A. N. Syn. Commun. 2010 (LSYC-2009-3951), in press.

[21]. Abdel-Latif, E.; Mustafa, H. M.; Etman, H. A.; Fadda, A. A. Russ. J. Org Chem. 2007, 43, 443-448.

[22]. Fadda, A. A.; Abdel-Latif, E.; Bondock, S.; Samir, A. Syn. Commun. 2008 $38,4352-4368$

[23]. Fadda, A. A.; El-Zemaity, M. T.; Gerges, M. M.; Refat, H. M.; Biehl E. R. Heterocycles 1996, 43, 23-32. 